\title{
EFFECT OF LACTATION STAGES ON SOME BLOOD SERUM BIOCHEMICAL PARAMETERS AND MILK COMPOSITION IN DAIRY COWS
}

\author{
EMAN M. ABD-EL NASER*; GHADA A.E. MOHAMED ${ }^{*}$ and HANAN K. ELSAYED ${ }^{* *}$ \\ ${ }^{*}$ Animal Health Research Institute, Assiut Branch. \\ *** Dept. of Animal Med., Fac. of Vet. Med., Assiut Univ. Assiut Egypt; Animal Health Research Institute, Assiut, Egypt. \\ Email: eman191069@yahoo.com
}

\begin{tabular}{|c|c|}
\hline & ABSTRACT \\
\hline Received at: $21 / 6 / 2014$ & $\begin{array}{l}\text { This study was conducted using Forty five dairy cows selected randomly from } \\
\text { small different farms. Blood and milk samples were collected during three stages }\end{array}$ \\
\hline Received at: 9/7/2014 & $\begin{array}{l}\text { of lactation (early, middle and late), on each serum sample total proteins, } \\
\text { albumin, glucose, urea, total lipids, cholesterol, triglycerides, calcium, } \\
\text { phosphorus and magnesium were determined. In each milk sample fat \%, total } \\
\text { proteins, calcium, phosphorous, and magnesium levels were measured. A } \\
\text { significant effect of the lactation stages were observed on glucose, urea, total } \\
\text { lipids, cholesterol, triglycerides, and calcium, while there were no significant } \\
\text { differences during the three lactation stages on serum total protein, albumin, } \\
\text { phosphorus and magnesium. In case of the examined milk samples there were no } \\
\text { significant differences in fat \%, urea, calcium, phosphorus and magnesium in the } \\
\text { different lactation stages. While, there was a significant increase in milk protein } \\
\text { in the middle and late lactation stages. }\end{array}$ \\
\hline
\end{tabular}

Key words: Dairy cows, lactation stages, biochemical alterations, milk composition.

\section{INTRODUCTION}

At the beginning of lactation, dairy cows have to cope with the high energy and protein demands for milk synthesis at the time when nutrient intake is low. In an effort to obtain the energy necessary for milk production, the cows use up their bodily reserves, predominately fats. An energy deficit at the beginning of lactation negatively impacts, health efficiency and reproduction performance of dairy cows (Lubojacká et al., 2005 and Mulligan et al., 2006).

Mobilizing energy and protein from body tissue stores and repartition of nutrients away from extramammary tissues are the primary alternatives to supply sufficient nutrients for milk production during the first weeks of lactation (Kessel et al., 2008). The main problem of that period is the limited intake capacity for dry matter, as a consequence of which dairy cows are unable to cover their energy need from feeds (Wathes et al., 2009).

Blood biochemical attributes are important indicators of the metabolic activity in lactating animals (Karapehlivan et al., 2007). During lactation, secretary cells of mammary gland utilize $80 \%$ of the blood circulating metabolites for milk synthesis, depending on the speed of infiltration of precursors of milk compounds (i.e. free amino acids, glucose and fatty acids).

All animals require minerals such as calcium $(\mathrm{Ca})$, magnesium $(\mathrm{Mg})$, and phosphorus $(\mathrm{P})$ for growth, reproduction and lactation, which often affect specific requirements, and serve as catalytic components of enzymes or regulate several mechanism involved just in pregnancy and lactation (Tanritanir et al., 2009 and Samardzija et al., 2011). Especially at the beginning of lactation, mobilization of $\mathrm{Ca}$ from bone and increased absorption from the gastrointestinal tract are required to re-establish homeostasis, which have to react to a tremendous increase in demand for Ca (Liesegang, 2008 and Lohrenz et al., 2010).

Milk, the outcome of various biochemical activities in mammary secretary cell is composed of fat, protein, carbohydrates, enzymes, vitamins and various minerals. The composition of milk is influenced by various factors, i.e., stage of lactation, lactation number, breed, feeding pattern, environmental and diseased condition of the udder (Brinez et al., 2003).

The fat, protein and urea contents of milk vary according to stage of lactation. Fat content is high immediately after calving but soon begins to fall, and continues to do so for 10 to 12 weeks, after 
which it tends to rise again until the end of the lactation (Chilliard et al., 2003, 2007).

The aim of the present work to study the effect of the different lactation stages on some biochemical serum constituents and some milk composition.

\section{MATERIALS and METHODS}

Forty five dairy cows selected randomly from small different farms and divided into three groups, depending on the day postpartum of sampling, each group consists of fifteen dairy cow: group I: 3-6 weeks after calving (early stage of lactation), group II: 15-20 weeks after calving (middle stage of lactation), group III: 22-38 weeks after calving (late stage of lactation).

\section{Blood samples:}

Jugular blood samples were collected in plain vacutainer tubes for blood serum biochemistry. The blood was allowed to clot and centrifuged, then clear blood serum was separated and stored at $-20^{\circ} \mathrm{C}$ until analysed.

On each serum sample total proteins, albumin, glucose, urea, total lipids, cholesterol, triglycerides, calcium, phosphorus and magnesium were determined by means of commercial kits (STANBIO laboratories, diagnostic company, USA) and measured using the spectrophotometer (Coles, 1986).

\section{Milk samples:}

Fresh $100 \mathrm{ml}$ raw milk was obtained from cows. Samples of milk were cooled down until $6{ }^{\circ} \mathrm{C}$ was reached. Samples were kept at the same temperature during the determination of milk fat $\%$ by milkoscan analyzer. Within an hour after milking, milk was skimmed by centrifugation at 3000 r.p.m for $15 \mathrm{~min}$ to remove their creams and cells. Samples were then treated with $0.1 \mathrm{M}$ hydrochloric acid at the controlled $\mathrm{pH}$ of 4.8 for casein precipitation. Treated samples were recentrifuged and the supernatants (Whey) were collected. Total protein, urea, calcium, phosphorus magnesium levels were measured by using spectrophotometer through reagent kits supplied commercially by (STANBIO laboratories, diagnostic company, USA).

\section{Statistical analysis:}

All the results were expressed as mean values and standard deviation (SD). Recorded data were analyzed statistically using analysis of variance (ANOVA). Differences among the groups at $p<0.05$ and $p<0.01$ were considered as significant. The statistical differences between means were estimated by Duncan's Multiple Range test. The computation was facilitated by statistical package SPSS (2000).

\section{RESULTS}

As shown in Tables 1, 2 and 3, all serum investigated parameters were significantly $(\mathrm{P}<0.05)$ and $(\mathrm{P}<0.01)$ influenced by stage of lactation except serum total proteins, albumin, phosphorus and magnesium.

Serum glucose (Table 1) was significantly $(\mathrm{P}<0.05)$, increased in both the middle and late stage of lactation in comparing with the early stage of lactation. Serum urea (Table 1) was significantly $(\mathrm{P}<0.01)$, increased with the progress of lactation.

Serum total lipids and cholesterol (Table 2), were significantly $(\mathrm{P}<0.05)$, increase in the middle stage of lactation and showed highly significant $(\mathrm{P}<0.01)$ increase with the late stage of lactation. Serum triglycerides (Table 2) was significantly higher $(\mathrm{P}<0.05)$ at the late stage of lactation.

Ca serum levels (Table 3) showed a significant $(\mathrm{P}<0.05)$ increase in both the middle and late stage of lactation. There were no significant changes in both phosphorus and magnesium in the different lactation stages.

No significant differences in milk, fats $\%$, urea (Table 4), calcium phosphorus and magnesium (Table 5), in the different lactation stages were detected. While there was a significant $(\mathrm{P}<0.05)$ increase in milk protein in the middle and late lactation stages.

Table 1: Mean values $( \pm \mathrm{SD})$ of total proteins, albumin, glucose and urea serum contents in dairy cows during different stages of lactation.

\begin{tabular}{cccc}
\hline Parameter & $\begin{array}{c}\text { Early stage of lactation } \\
(3-6) \text { week }\end{array}$ & $\begin{array}{c}\text { Middle stage of lactation } \\
(15-20 \text { week })\end{array}$ & $\begin{array}{c}\text { Late stage of lactation } \\
(22-38 \text { week })\end{array}$ \\
\hline Total proteins $(\mathrm{g} / \mathrm{dl})$ & $\mathbf{7 . 9 1} \pm \mathbf{1 . 3 7}$ & $\mathbf{7 . 5 8} \pm \mathbf{1 . 3 3}$ & $\mathbf{7 . 4 7} \pm \mathbf{1 . 3 8}$ \\
\hline Albumin $(\mathrm{g} / \mathrm{dl})$ & $\mathbf{3 . 0 8} \pm \mathbf{0 . 4 4}$ & $\mathbf{2 . 7} \pm \mathbf{0 . 3 4}$ & $\mathbf{2 . 6} \pm \mathbf{0 . 3 7}$ \\
\hline Glucose $(\mathrm{mg} / \mathrm{dl})$ & $\mathbf{3 6 . 4 7} \pm \mathbf{5 . 9}$ & $\mathbf{4 0 . 0} \pm \mathbf{5 . 5}$ & $\mathbf{4 2 . 5} \pm \mathbf{6 . 1}$ \\
\hline Urea $(\mathrm{mg} / \mathrm{dl})$ & $\mathbf{2 5 . 8 5} \pm \mathbf{8 . 9 1}$ & $\mathbf{2 9 . 8 5} \pm \mathbf{9 . 6}$ & $\mathbf{2 9 . 8 3} \pm \mathbf{9 . 4}$ \\
\hline
\end{tabular}

*Significant at $(\mathrm{P}<0.05)$ and ** $(\mathrm{P}<0.01)$ 
Table 2: Mean values $( \pm \mathrm{SD})$ of total lipids, cholesterol, and triglycerides serum contents in dairy cows during different stages of lactation.

\begin{tabular}{cccc}
\hline Parameter & $\begin{array}{c}\text { Early stage of lactation } \\
(3-6) \text { week }\end{array}$ & $\begin{array}{c}\text { Middle stage of lactation } \\
(15-20 \text { week })\end{array}$ & $\begin{array}{c}\text { Late stage of lactation }(22- \\
38 \text { week })\end{array}$ \\
\hline Total lipids $(\mathrm{mg} / \mathrm{dl})$ & $\mathbf{2 9 2 . 1 6} \pm \mathbf{1 5 . 0 3}$ & $\mathbf{3 0 7 . 8} \pm \mathbf{1 5 . 9 8 *}$ & $\mathbf{3 2 0 . 9 8} \pm \mathbf{1 7 . 6 7 * *}$ \\
\hline Cholesterol $(\mathrm{mg} / \mathrm{dl})$ & $\mathbf{1 2 3 . 4} \pm \mathbf{4 2 . 1}$ & $\mathbf{1 3 0 . 1} \pm \mathbf{3 4 . 6} *$ & $\mathbf{1 3 5 . 2} \pm \mathbf{3 6 . 4} *^{* *}$ \\
\hline Triglycerides $(\mathrm{mg} / \mathrm{dl})$ & $\mathbf{9 . 4} \pm \mathbf{0 . 7 2}$ & $\mathbf{9 . 8 5} \pm \mathbf{1 . 7}$ & $\mathbf{1 0 . 8} \pm \mathbf{1 . 8}$ \\
\hline
\end{tabular}

*Significant at $(\mathrm{P}<0.05)$ and ** $(\mathrm{P}<0.01)$

Table 3: Mean values $( \pm \mathrm{SD})$ of calcium $(\mathrm{Ca})$, phosphorus $(\mathrm{P})$ and magnesium $(\mathrm{Mg})$, serum contents in dairy cows during different stages of lactation.

\begin{tabular}{cccc}
\hline Parameter & $\begin{array}{c}\text { Early stage of lactation } \\
(3-6) \text { week }\end{array}$ & $\begin{array}{c}\text { Middle stage of lactation } \\
(15-20 \text { week })\end{array}$ & $\begin{array}{c}\text { Late stage of lactation }(22- \\
38 \text { week })\end{array}$ \\
\hline Calcium $(\mathrm{mg} / \mathrm{dl})$ & $\mathbf{5 . 6 \pm 0 . 6 4}$ & $\mathbf{6 . 1} \pm \mathbf{0 . 2 9 *}$ & $\mathbf{6 . 0 1} \pm \mathbf{0 . 7 9 *}$ \\
\hline phosphorus $(\mathrm{mg} / \mathrm{dl})$ & $\mathbf{3 . 4 9} \pm \mathbf{0 . 2 0}$ & $\mathbf{3 . 9 5} \pm \mathbf{0 . 8 5}$ & $\mathbf{3 . 3 4} \pm \mathbf{0 . 1 9}$ \\
\hline Magnesium $(\mathrm{mg} / \mathrm{dl})$ & $\mathbf{1 . 9} \pm \mathbf{0 . 0 5}$ & $\mathbf{2 . 1 1} \pm \mathbf{0 . 1 4}$ & $\mathbf{2 . 1 0} \pm \mathbf{0 . 1 9}$ \\
\hline
\end{tabular}

*Significant at $(\mathrm{P}<0.05)$

Table 4: Mean values $( \pm \mathrm{SD})$ of fat $\%$, total protein, and urea, in milk contents in dairy cows during different stages of lactation.

\begin{tabular}{cccc}
\hline Parameter & $\begin{array}{c}\text { Early stage of lactation } \\
(3-6) \text { week }\end{array}$ & $\begin{array}{c}\text { Middle stage of lactation } \\
(15-20 \text { week })\end{array}$ & $\begin{array}{c}\text { Late stage of lactation (22- } \\
38 \text { week })\end{array}$ \\
\hline Fat \% & $\mathbf{2 . 6 8} \pm \mathbf{0 . 6 5}$ & $\mathbf{2 . 4 8} \pm \mathbf{0 . 5 4}$ & $\mathbf{1 . 9 7 \pm 0 . 4 2}$ \\
\hline Total proteins $(\mathrm{g} / \mathrm{dl})$ & $\mathbf{3 . 9 3} \pm \mathbf{0 3 8}$ & $\mathbf{4 . 7 8} \pm \mathbf{0 . 4 1 *}$ & $\mathbf{4 . 9 7} \pm \mathbf{0 . 2 9 *}$ \\
\hline Urea $(\mathrm{mg} / \mathrm{dl})$ & $\mathbf{5 . 9} \pm \mathbf{1 . 5}$ & $\mathbf{5 . 6} \pm \mathbf{1 . 4 2}$ & $\mathbf{5 . 5} \pm \mathbf{1 . 4 3}$ \\
\hline
\end{tabular}

*Significant at $(\mathrm{P}<0.05)$

Table 5: Mean values $( \pm \mathrm{SD})$ of calcium, phosphorus and magnesium, in milk contents in dairy cows during different stages of lactation.

\begin{tabular}{cccc}
\hline Parameter & $\begin{array}{c}\text { Early stage of lactation } \\
(3-6) \text { week }\end{array}$ & $\begin{array}{c}\text { Middle stage of lactation } \\
(15-20 \text { week })\end{array}$ & $\begin{array}{c}\text { Late stage of lactation (22- } \\
38 \text { week })\end{array}$ \\
\hline Calcium $(\mathrm{mg} / \mathrm{dl})$ & $\mathbf{1 . 9} \pm \mathbf{0 . 2 3}$ & $\mathbf{2 . 3} \pm \mathbf{0 . 2 7}$ & $\mathbf{2 . 0 5} \pm \mathbf{0 . 2 4}$ \\
\hline Phosphorus $(\mathrm{mg} / \mathrm{dl})$ & $\mathbf{1 . 4 5} \pm \mathbf{0 . 2 2}$ & $\mathbf{1 . 7 9 \pm \mathbf { 0 . 1 9 }}$ & $\mathbf{1 . 7 4} \pm \mathbf{0 . 2 1}$ \\
\hline Magnesium $(\mathrm{mg} / \mathrm{dl})$ & $\mathbf{1 . 3 3} \pm \mathbf{0 . 2 0}$ & $\mathbf{1 . 6 4} \pm \mathbf{0 . 2 3}$ & $\mathbf{1 . 4 6} \pm \mathbf{0 . 2 3}$ \\
\hline
\end{tabular}




\section{DISCUSSION}

Lactation stage is one of the important causes of variation in concentrations of blood metabolites in dairy cows (Vazquez-Anon et al., 1994 and Yaylak et al., 2009). Lactation phases affect significantly the metabolic profile and so the variation recorded during different physiological phases is expected.

The substantial decreases in serum concentrations of total protein, albumin with the progress of lactation were agreeable with previous studies (Cavestany et al., 2005). These decreases may reflect the maternal requirements of proteins for milking and providing immunoglobulins (Roubies et al., 2006 and Mohri et al., 2007).

The most important indicators of energy status of ruminants are glucose, cholesterol and triglycerides (Pechová and Pavlata, 2005). The blood glucose was significantly higher in middle and late lactation than the early lactation dairy cows Slanina et al. (1992), revealed the same results which agree with the present findings. The lowered means of blood glucose concentrations in early stage of lactation were due to large amount of blood glucose with drawl by the mammary gland for the synthesis of milk lactose (Kapple et al., 1984 and Nale, 2003).

The urea nitrogen values differ significantly among different groups of lactating cows. The mean blood urea value in the middle and late lactation stages was significantly increased as compared to the early lactation stage. Poso and Lindberg (1994) revealed lowered urea concentration after parturition which agrees with the present findings. Increase in blood urea nitrogen levels in middle and late lactation periods could be either due to increased deamination or increased protein intake (Roubies et al., 2006). Both increased levels of serum urea and low percentage of serum proteins confirm that urea was not fully used for the milk protein production, which points to energy deficiency conditions (Wathes et al., 2009).

Total lipids, and cholesterol were significantly affected by the physiological status, both showed substantial increases during the middle and late stage of lactation, while triglycerides showed a significant increase in the late stage of lactation. Probably because, around calving, there is an increase in the demands for regulatory mechanism, responsible for all the processes involved with preparation for milking (Roche et al., 2009). At this purpose, characteristic changes in lipid metabolism were found during pregnancy and lactation in most mammals, where Endocrine profiles change and lipolisis and lipogenesis are regulated to increase lipid reserve during pregnancy, and, subsequently, these reserves are utilized following parturition and the initiation of lactation (Nazifi et al., 2002 and Roche et al., 2009).

Concerning the electrolytes serum levels, all animals require minerals for growth, reproduction and lactation (Samardzija et al., 2011). There was drop in calcium level during early stage of lactation, as the stage of lactation progresses the serum calcium level increased which corroborates with the findings of Nale (2003). These results could be due to impaired absorption of food metabolites from the gastrointestinal precursor, excessive losses through urine, colostrums as it was much more drained in the colostrums during excessive milking and due to insufficient mobilization from the skeleton (Liesegang, 2008 and Brezezinska and Krawczyk, 2009). Moderate depression in the levels of phosphorus might be due to the necessity of it for the colostrums synthesis (Rook and Thomas, 1983 and Szenci et al., 1994) and enhanced carbohydrate metabolism.

Magnesium plays a vital role during the metabolism of carbohydrates, lipids, nucleic acids and proteins. In present investigation serum magnesium concentration in different lactation stages of dairy cows did not differ significantly.

Stage of lactation significantly influences the composition of raw milk of dairy cows (Brinez et al., 2003). Factors predisposing to general or mammary gland diseases should be evaluated in combination with the major milk components (fat and protein) by measuring urea in milk as indicators of a balanced diet (Haman and Krömker, 1997).

Milk fat can increase or decrease depending on ration composition. Early lactation cows have a tendency to mobilize body reserves while ingesting rations that are low in effective fiber will tend to decrease milk fat levels (Eicher, 2004).

Lower milk fat content is frequently used in farms as an indicator of sub-acute ruminal acidosis and to predict the effectiveness of diet structure for chewing (Bergamini, 1987 and Merterns, 1997). Low milk fat content is caused by a lack of major precursor-acetic acid in rumen that is produced in insufficient quantity (Illek, 2008). Generally, if milk protein content increased and milk fat content decreased it leads to sub-clinical acidosis (Pavlata et al., 2008).

The significant increase in the levels of milk proteins, with the different stages of lactation are constant with the observation made by (Marenjak et al., 2006).

Monitoring of urea in milk is an indicator of metabolic nitrogen balance of cows (Jílek et al., 2006), which characterise their health, and reproductive ability (Hanuš et al., 2000). Acquired 
results of milk urea were without significant confirmation.

Milk calcium and phosphorus output is directly related to milk yield, as milk phosphorus concentration is constant (Valk et al., 2002). In fact, increasing the milk production, more minerals from the ingested amount is transferred to milk and less is excreted with faeces. The decreasing in phosphorus and magnesium concentration in mature milk was likely in part due to dilution resulting from increased milk production (Valk et al., 2002).

\section{REFERENCES}

Bergamini, F.P. (1987): Report of pathology (not mammary) from aspects of quality of bovine milk. In Atti Soc. Ital. Buiatria. vol.19, 1987, p. 89-99.

Brinez, W.J.; Valbuena, E.; Castro, G.; Tovar, A.; Ruiz, R.J. and Roman, R. (2003): Effects of breed, season, lactation stage and parity number on composition of raw milk of crossbreed cows. Revista Cietifica 13(6): 490-498.

Brzezinska, M. and Krawczyk, M. (2009): Changes of the mineral profile of Serum of goats in various physiological states. Journal of Elementology, T.14. P. 649-656.

Cavestany, D.; Blance, J.E.; Kucsar, M.; Uriarte, G.; Chilibroste, P.; Meikle, A.; Febl, H.; Ferraris, A. and Krall, E. (2005): Studies of the transition cow under a pasture-based milk production system:Metabolic profiles. J. Vet. Med. A.52:1-7.

Chilliard, Y.; Ferlay, A.; Rouel, J. and Lamberet, G. (2003): A review of nutritional physiological factors affecting goat milk lipid synthesis and lipolysis. J. of Dairy Sci. 86, 751-1770.

Chilliard, Y.; Glasser, F.; Ferlay, A.; Bernard, L.; Rouel, J. and Doreau, M. (2007): Diet, rumen bio-hydrogenation and nutritional quality of cow and goat milk fat. Europian Journal of Lipid Science and Technology. (EJLST) 109, 828-855.

Coles, E.H. (1986): Veterinary Clinical Pathology. $4^{\text {th }}$ Edn., W.B. Saunders Company, Philadelphia, London, Toronto.

Eicher, R. (2004): Evaluation of the metabolic and nutritional situation in dairy herds: Diagnostic use of milk components. Proceedings of the world Buiatrics congress, 11-16 july, Quebec, Canada.

Hamann, J. and Kromker, V. (1997): Potential of specific milk composition variables for cow health management. In Livestock Production Science, vol. 48, 1997, p. 201-208.

Hanus, O.; Leray, O.; Pytloun, J.; Menegain, E.; Trossat, P.; Gencurova, V.; Matous, E. and Dolinkova, A. (2000): A retrospective of the international laboratory integration impact on reliability of milk analysis data. In Acta Universitatis Agriculture et Silviculturae Mendelianae Brunensis (Brno), vol. 48, 2000, no. 4, p.121-131.

Illek, J. (2008): Causes of metabolic disorders for dairy cows and their effect on the quantity and quality production. In Days of nutrition and veterinary dietetics VIII. UVL: Košice, p. 32-35 ISBN 978-80-8077-079-2.

Jilek, F.; Řehak, D.; Volek, J.; Štipkova, M.; Nemcova, E.; Fiedlerova, M.; Rajmon, R. and Švestkova, D. (2006): Effect of herd, parity stage of lactation and milk yield on urea concentration in milk. In Czech Journal of Animal Science, 2005, vol. 51, no. 12, p. 510-517.

Kappel, L.C.; Ingraham, R.H.; Morgan, E.B. and Babock, D.K. (1984): Relationship between fertility and blood glucose and cholesterol concentration in Holstein cows. Am. J. Vet. Res.45: 2607-2612.

Karapehlivan, M.; Atakisi, E.; Atakisi, O.; Yucart, R. and Pancarci, S.M. (2007): Blood biochemical parameters during the lactation and dry period in Tuj ewes. Small Ruminant Research 73, 267-271.

Kessel, S.; Strohel, M.; Meyer, H.H.D.; Hiss, S.; Sauerwein, H.; Schwarz, F.J. and Bruckmeyer, R.M. (2008): Individual variability in physiological adaptation to metabolic stress during early lactation in dairy cows kept under equal conditions. J. of Anim. Sci. T. 86. P. 2903-2912.

Liesegang, A. (2008): Influence of anionic salts on bone metabolism in periparturient dairy goats and sheep. J. of Dairy Sci., T.91. P. 24492460

Lohrenz, A.K.; Duske, K.; Schneider, F.; Nurnberg, K.; Losand, B.; Seyfert, H.M.; Metges, C.C. and Hammon, H.M. (2010): Milk performance and glucose metabolism in dairy cows fed rumen protected fat during mid lactation. J.of Dairy Sci., T.93. P. 5867-5876.

Lubojacká, V.; Pechová, A.; Dvořák, P.; Drastich, V.; Kummer, J. and Poul. (2005): Liver statuses following supplementation with Fat in Dairy Cows Diets. Acta Veterinaria Brno, vol.74, p.217- 224.

Marenjak, T.S.; Poljicak-milas, N. and Zdelar-Tuk. (2006): A study of the effects of nutrition and seasonal, climatic factors on milk production and biochemical parameters in blood and milk of simmental cows. Tierarzliche Umschaw 61(7): 357-362.

Mertens, D.R. (1997): Creating a system for meeting the fiber requirements of dairy cows. In J. of Dairy Sci., vol. 80, 1997, p. 1463-1481.

Mohri, M.; Sharifi, K. and Eidi, S. (2007): Hematology and serum biochemistry of Holstein dairy calves: age related changes 
and comparison with blood Composition in adults. Res. in Vet. Sci., T.83. P. 30-39.

Mulligan, F.J.; Ogrady, L.O.; Rice, D.A. and Doherty, M.L. (2006): A herd health approach to dairy cow nutrition and production diseases of the transition cow. Animal Reproduction, 96, 331-353.

Nale, R.A. (2003): Metabolic profiling in buffaloes before and after parturition. M.V.Sc. thesis submitted to MAFSU, Nagpur: 29-34.

Nazifi, S.; Saeb, M. and Ghavami, S.M. (2002): Serum lipid profile in Iranian fat-tailed sheep in late pregnancy, at parturition and during the post-parturition period. J. of Vet. Med., 49, 9-12.

Pavlata, L.; Pechova, A. and Dvorak, R. (2008): Differential diagnosis of cows lying down syndrome. In Veterinářství, vol. 58, 2008, p.43-51.

Pechova, A. and Pavlata, L. (2005): Use of metabolic profiles of dairy cows in the control diet. In Nutrition of cattle in terms of production and preventive medicine. p. 102111. ISBN 80-86542-08-4.

Poso, A.R. and Lindberg, L.A. (1994): Plasma protein synthesis and serum amino acids in dry and lactating dairy cows. J. Vet. Med., Series A. 41 (1): 72-75.

Roche, J.R.; Frggens, N.C.; Kay, J.K.; Fisher, M.W.; Stafford, K.J. and Berry, D.P. (2009): Invited review: Body condition score and its association with dairy cow productivity, health and welfare. J. of Dairy Sci. T. 92. P. 5769-5801.

Rook, J.A.F. and Thomas, P.C. (1983): Nutritional physiology of farm animals Ed 1.Longman Inc. New York.

Roubies, N.; Panouis, N.; Fytianou, A.; Katsoulos, P.D.; Giadinis, N. and Karatzias, H. (2006): Effects of age and reproductive stage on certain serum biochemical parameters of Chios sheep under greek rearing conditions. J. Vet. Med. A, T. 53. P. 277-281.

SlaninaL, L.; Beseda, I.; Hlinka, D.; Illek, J.; Kovac,
G.; Kroupova, V.; Lehocky, J.; Michna, A.; Rossow, N.; Sokol, J. and Vajda, V. (1992): Metabolic profile of cattle in relation to health and production.1992, ŠVS SR, Bratislava, 115 p. ISBN 80-7148-001-0.

Samardzjia, M.; Dobranic, T.; Lipar, M.; Harapin, I.; Prvanovic, N.; Girzelji, J.; Greguric Gracner, G.; Dobranic, V.; Radisic, B. and Duricic, D. (2011): Comparison of blood serum macromineral concentrations in meat and dairy goats during puerperium. Veterinarski Ahriv. T. 81. P. 1-11.

SPSS, (2000): Sample Power statistics, SPSS 11.5, Syntax reference Guide for SPSS Base. SPSS Inc., 233 South Wacker Drive, Chicago.

Szenci, O.; Chew, B.P.; Bajcsy, A.C.; Szabo, P. and Brydl, E. (1994): Total and Ionized Calcium in parturient dairy cows and their calves. J. of Dairy Sci., T. 77. P. 1100-1105.

Tanritanir, P.; Dede, S. and Ceylan, E. (2009): Changes in some macro minerals and biochemical parameters in female healthy siirt hair goats before and after parturition. J. ANIM VET ADV, T. 8. P. 530-533.

Vazquez-Anon, M.; Bertics, S.; Luck, M.; Grummer, $R$. and Pinheiro, J. (1994): Peripartum liver Triglyceride and plasma metabolites in dairy cows. J. Dairy Sci.77: 1521-1528.

Valk, H.; Sebek, L.B.J. and Beynen, A.C. (2002): Influence of Phosphorus intake on excretion and blood plasma and saliva concentrations of phosphorus in dairy cows. J. Dairy Sic. T. 85. P. 2642-2649.

Wathes, D.C.; Cheng, Z.; Chowdhury, W.; Fenwick, M.A.; Fitzpatrick, R.; Morris, D.G.; Patton, J. and Murphy, J.J. (2009): Negative energy balance alters global gene expression and immune responses in the uterus of postpartum dairy cows. Physiol Genomics.

Yaylak, E.; Yenisey, C. and Seyrek, K. (2009): Effects of lameness, stage of lactation and body condition score on some blood parameters in Holstein cows. Asian J. Anim. Vet. Adv. 4(5): 245-251.

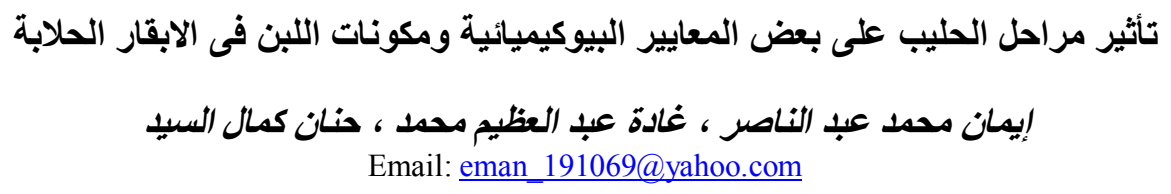

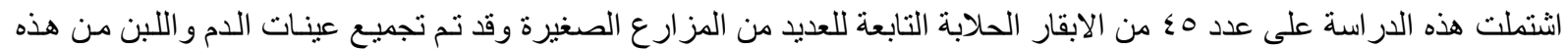

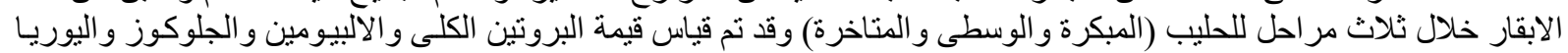

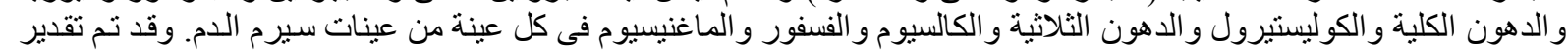

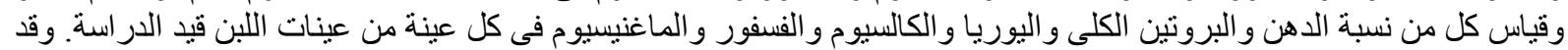

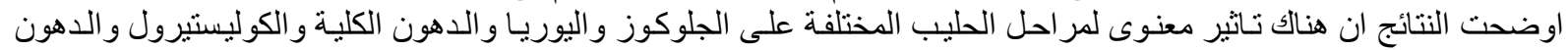

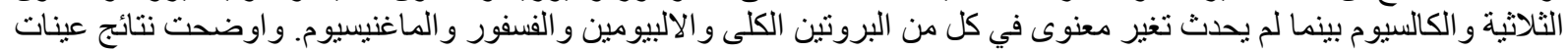

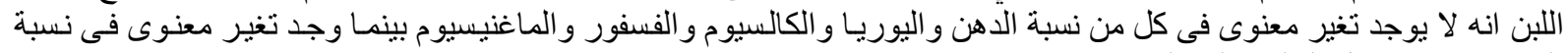

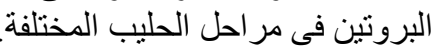

